\title{
Result of Development Investment Lychees Product in Viet Nam
}

\author{
Dang Phi Truong \\ Thai Nguyen University of Economics and Business Administration, Viet Nam \\ Le Thi Yen \\ Thai Nguyen University of Economics and Business Administration, Viet Nam
}

\begin{abstract}
This study was conducted to analyse the current status of development investment lychee products in Vietnam, results of investment and lychee products development. Based on that analysis, the author's analyze the achievements and limitations as basis to propose solutions contribute to improving the investment effectiveness in developing lychee products in Vietnam. The data in the study were collected from the surveys of lychee growers in Vietnam, Descriptive statistics method, Analytical comparisons were also used to analyze data in this study.
\end{abstract}

Keywords: Development investment, lychees, Vietnam.

\section{Introduction}

Vietnam is a country with a long-term agricultural economy with the people living by agriculture account for $70 \%$ of the population, which is country with tropical climate, is divided into many different regions so there are also different characteristics. Provinces and regions have fundamental advantages such as in the Northern mountainous provinces, Central Highlands, Southeast, Mekong River Delta ... with economic and environmental advantages, it also contains potentials on land exploitation, minerals and specialty products of local. Wherein the different regions have different agricultural products bearing own characteristics of each region in general and each province in particular.

According to statistics from the National Office of Intellectual Property, Vietnam has nearly 1,000 specialty products including agricultural, aquatic and forestry products of many localities, many products have a small scope in the region district, commune or village. Along with that, rural areas have more than 5397 craft villages and villages that produce different types of products, most of them are small and medium-sized villages, which the number of traditional craft villages accounts for about $15 \%$ of the total (Source: Ministry of Agriculture and Rural Development, 2015).

The diversity of natural, cultural and ethnic conditions has created for Vietnam a lot of specialty products, traditional products bearing bold cultural features of ethnic groups and localities, making a specials and unique feature origin of Vietnam. With that potential, the sustainable development of products with advantages does not only make economic sense (improve 
standards of living, create jobs for people ...) but also has social meaning of profound from the perspective of social stability, poverty reduction, political stability...

Lychee is one of the typical agricultural products of Vietnam, the results from investment in developing lychee products have contributed to a great change to the local socio-economy as well as to life of local people. Therefore, studying the results of investment in developing lychee product is necessary, thereby pointing out the achievements, limitations of investment in lychee product development and proposing recommendations to promote investment in lychee development in Vietnam.

\section{Overview of research}

Investment in agricultural development, the influence of agricultural products on socioeconomic development has received the attention not only of researchers but also of policy makers: Dominique Barjolle et al (2009) focused on methods to assess the impact of territorial geographical indications (economic, social and environmental), the results show that the economic benefits are is the only purpose in implementing product protection projects with geographical indications. Or from the point of view of Carina Folkeson (2005), the author reviews the economic impacts of geographical indications on producers. The research results also show that the production of products bearing geographical indications in the EU has in many cases contributed to rural development, although the development between different regions and different products. The study also concluded that statutory protection is necessary for benefits arising from the production of geographic indications to beneficial for producers and related actors.

Pradyot R. Jena, Ulrike Grot, (2010) used the data from a survey of 300 rice farmers in a northern Indian province namely Uttarakhand. In the study, the author analyzes the total profit, determines the net benefits of Basmati rice bearing geographic indications with other plants in the same locality but does not have a production certificate with specific geographical indications. The author selected plants without certification geographic indications as sugarcane. The research results show that Basmati rice is more profitable than other crops, after that, the author studies the factors affecting the decision to produce products bearing geographical indications, one of the number of factors mentioned is the ability to access policies, the number of workers in the household ...Simultaneously, the author used the marginal benefit analysis method as a basis for this research implementation, straight line regression (OLS) used by the author to analyze the impact of geographical indications. Le Dinh Thang (1993), Nguyen Sinh Cuc (2001) gave views on production households in his study, each study has different specific points of view about producers but has a common point unifying the viewpoint that household production are units involved in production activities of exploiting and processing products related to agriculture.

A number of other studies have also been conducted to identify factors affecting household incomes in specific areas, in different localities such as: Nguyen Quoc Nghi et al (2011), Nguyen Van Thieu et al (2011), Nguyen Van Toan et al (2012), Huynh Thi Dan Xuan (2012), Nguyen Thi Hong Hanh et al (2013) ...Primary data is also selected by the authors for their research, which is also the similarities most clearly with the research related to the consideration which factors affecting household incomes, in particular, here are the agricultural production households studied by the authors. The purpose of the studies: to determine the average income of households, and the factors that affect to household income and the relationship between them.

With the collected data, the author conducted the analysis using descriptive modeling and statistical methods, the models used were OLS models, this is a relatively used model popular with studies in Vietnam related to factors affecting household income in different areas, this is 
the model used relatively common with studies in Vietnam related to factors affecting household's income in different sectors.

\section{Research methodology}

\subsection{Research sites}

Lychee is a typical product of Vietnam, in Vietnam, there are two most well-known localities for lychee products: Hai Huong and Bac Giang provinces. These are two localities where lychee products are recognized as products with geographical indications and exported to difficult markets such as China, the US and EU.

This study selected Bac Giang province as a research area that meets requirements of the representativeness of the data collected.

\subsection{Data collection methods}

Primary data were collected from surveys of households in Bac Giang Province, these households which are households growing lychee and knowledgeable about the lychee.

To perform statistical calculations to ensure the minimum sample size, there are many different views on the choice of the minimum sample. There are many different concepts about the survey sample: Research conducted a survey of 150 households in the province of Bac Giang using questionnaires were standardized, after the data is collected, author performs data cleaning and data entry into Excel software. After cleaning the data, there were 24 questionnaires that did not meet the requirements, the author made the removal of these surveys, retaining 126 questionnaires that meet the questionnaire and use 126 surveys to perform Statistical calculations.

\subsection{Data analysis methods}

The data were collected after will be performed calculations and analysis, descriptive statistical methods and comparison method used by the author in this study. The calculation results will be interpreted to analyze issues that need research.

\section{Research Findings}

\subsection{About production of average lychee products}

As one of the typical products of Bac Giang province, Vietnam, Thieu litchi received the attention of local authorities at all levels to focus on product development. At the same time, local people also consider this as one of the main products, creating income for people.

\subsection{About output}

Product manufacturing lychee on average as one of the typical products of Bac Giang province, Vietnam, wich received the attention of local authorities at all levels to focus on product development. At the same time, local people also consider this as one of the main products, creating income for people. In order to achieve certain results for the lychee brand for the locality, development investment has an important position and role, in particular: Regarding the production of lychee production according to survey results from yard households. as follows: 
Table 1. Output of Lychee production

\begin{tabular}{|l|l|l|l|l|l|}
\hline Descriptive Statistics & N & Minimum & Maximum & Mean & Std. Deviation \\
\hline Quantity & 126 & 605 & 3100 & 1175.90 & 441.748 \\
\hline $\begin{array}{l}\text { Valid N } \\
\text { (listwise) }\end{array}$ & 126 & & & & \\
\hline
\end{tabular}

Source: Analysis results from the author's research data

The average lychee production of each household is 1175.90 quintals (the lowest is 605 and the highest is 3100 quintal / crop). There is a disparity between households in the output produced because the area of each household is different and the quality of care varies.

\subsection{Scale of average invested capital}

In order to achieve such results in the production of local lychee products, the scale of investment capital is relatively large. The result of investment capital for product development is as follows:

Table 2. Scale of investment capital

\begin{tabular}{|l|c|c|c|c|c|}
\hline \multicolumn{5}{|c|}{ Descriptive Statistics } \\
\hline & $\mathrm{N}$ & Minimum & Maximum & Mean & Std. Deviation \\
\hline Investment & 126 & 83 & 193 & 117.30 & 31.064 \\
\hline $\begin{array}{l}\text { Valid N } \\
\text { (listwise) }\end{array}$ & 126 & & & & \\
\hline
\end{tabular}

Source: Analysis results from the author's research data

In particular, details of investment items for lychee product development are as follows:

Table 3. Division of investment items

Unit: millions dong

\begin{tabular}{|l|c|}
\hline \multicolumn{1}{|c|}{ Investments } & Đầu tư \\
\hline 1. Regular investment & $\mathbf{9 7 , 6 5}$ \\
\hline Investments in employees & 44,63 \\
\hline Investment in fertilizer & 11,82 \\
\hline Investment in trimming & 8,15 \\
\hline Investment in harvest & 33,05 \\
\hline 2. Initial investment (machinery and equipment) - fixed investment & $\mathbf{1 9 , 6 5}$ \\
\hline Total Investments & $\mathbf{1 1 7 , 3 0}$ \\
\hline
\end{tabular}

Source: Analysis results from the author's research data

Can see that regular investments are investments accounted for the highest proportion, regular investments for households to grow lychee approximately 97.65 million

In the regular investment group, the investment in employee accounts for the largest proportion because it is quite agricultural work, needs the care, improvement and collection of human. In terms of initial investments - fixed investment in lychee growing, fixed investment usually 
invests in water pumps, irrigation systems, pruning tools and fruit harvest tools about 19.65 million VND.

\subsection{Effect of investment in developing lychee}

With the investment in developing lychee products, the investment efficiency is as follows:

Table 4. Net profit of lychee producers

Unit: millions dong

\begin{tabular}{|l|c|}
\hline \multicolumn{1}{|c|}{ Results } & The group has no geographical indications \\
\hline 1. Investment & 117,30 \\
\hline 2. Output (Earnings) & 205,85 \\
\hline 3. Net profit $(3=2-1)$ & 88,544 \\
\hline
\end{tabular}

Source: Analysis results from the author's research data

According to the calculation data, the net profit from investment of lychee farmers is on average VND 88,544 million. The results of survey and calculations are relatively appropriate when investment is high, household income will also be high, net profit from investment is also relatively high

\section{Conclusion}

This research was conducted to analyze the results of development investment lychee products. The research findings are the foundation for helping policy makers to use as a base to proposed policy recommendations for the country, local to develop products. At the same time, research is also useful reference works for students in economic majors which can be used for reference. However, in the future, if it is possible expand the scope of the study with other products, Research findings will be better.

\section{Recommendations}

In order to invest in lychee product development to bring better results, some recommendations are proposed by the author as follows:

Training courses on processing and preserving lychee products need to be organized from which can choose a wider range of product consumption methods more diverse for producers.

Training for households producing/ growing agricultural products about the skills of market development, when skilled in market development and exposure to customer needs for products, producers will know what customer requirements about their products and will adjust to suit the tastes and meet market demand: including in both quality as well as requirements when packaging and harvest products.

Strengthening support from competent state agencies to support people in credit loans, market access ...Rational use of resources in production and business of households, lychee growers to avoid input resource wasting.

\section{References}

Carina Folkeson (2005). Geographical Indications and Rural Development in the EU, school of economics and management, Lund University

Dominique Barjolle, Marguerite Paus, Anna Perret (2009). Impacts of Geographical Indications Review of Methods and Empirical Evidence, International Association of Agricultural Economists Conference, Beijing, China 
Huynh Thi Dan Xuan and colleagues (2011). Analysis of factors affecting the income of poultry farms in the Mekong Delta, Science Magazine - Can Tho University

Hoang Trong and Chu Nguyen Mong Ngoc (2008). Statistics in socio-economy, Statistical Publishing House

Le Dinh Thang (1993). Household economic development toward commodity production, Agricultural Publishing House, Hanoi

Nguyen Sinh Cuc (2001). Rural survey analysis in 2000.

Nguyen Thi Hong Hanh and colleagues, (2013). The impact of withdrawing agricultural land on lives of farmers in Van Lam district, Hung Yen province, Scientific journals and development No. 1, episode 11

Nguyen Dinh Tho (2012). Methods of scientific research in business: Design and implementation, Labor and Social Publishing House.

Nguyen Van Thang (2014). Research practices in economics and business administration course, National Economics University Publishing House

Nguyen Quoc Nghi (2011). Factors affecting income of ethnic minorities in the Mekong Delta, scientific journals vol 18

Nguyen Quoc Nghi (2011). Accessibility official capital of poor households. Banking Magazine, No. 7, 2011

Nguyen Van Thieu (2014). Factors affecting livelihoods and sustainable livelihood solutions for people in flooded areas in An Giang province.

Pradyot R. Jena, Ulrike Grot (2010). Does geographical indication (GI) increase producer walfare? A case study of Basmati rice in Northern India, the ISEE conference

Vu Thi Minh (2004). Developing fruit trees in mountainous areas of Quang Ninh province, National Economic University

Nguyen Van Toan (2012). Effects of P135 programs on the livelihoods of ethnic minorities in Huong Hoa district, Quang Tri province, science - magazine Hue University 3 episode number 72B.

Tabachnick, B.G., \& Fidell, L. S (2007). Using multivariate statistics (3rded.), New York: Harper Collins 